\title{
Monitoring Colonias Along the United States-Mexico Border
}

The Colonias Monitoring Program provides a publicly accessible, binational, GIS database to enable civic leaders and citizens to inventory, analyze, and monitor growth, housing, and infrastructure in border communities. High-technology tools are provided to support planning efforts and development along the border, using a sustainable and comprehensive approach. The collective information can be used by nongovernmental organizations in preparing grant and loan applications for community-improvement projects.

The U.S. Geological Survey (USGS) and the U.S. Department of Housing and Urban Development (HUD), in cooperation with the Mexican Instituto Nacional de Estadística Geografía e Informática (INEGI), have developed a joint project to create Internet-enabled geographic information systems (GISes) that will help cities along the United States-Mexico border manage issues related to urban growth and low-income housing developments.

HUD defines colonias as rural neighborhoods within 150 miles of the border that lack adequate infrastructure or housing, as well as other basic services. The colonias typically have high poverty rates, making it difficult for residents to pay for roads, sanitary-water and sewer systems, minimum-standard housing, street lighting, and other services.

Colonias are scattered along the border as makeshift settlements, commonly on private land. Because these settlements have been established outside the formally sanctioned governance of nearby cities and towns, colonias residents have traditionally struggled to gain access to the public services available in those communities.

\section{General Description}

This joint project delineated colonias, developed geospatial databases describing infrastructure and land use, and established a framework for distributing World Wide Web-based GIS decision-support systems for the sister-city areas. "Sister" or "twin" cities are those communities where a city in one country borders a city in another, creating a large urban area separated by administrative boundaries. To develop the GIS databases, we integrated data from The National Map (USGS), the U.S. Census Bureau, and INEGI and worked with binational partners, including Federal, State, county, and town representatives, as well as interested youth and advocacy groups.

Each Web-based mapping site incorporates common-base data layers, including transportation, digital orthophoto quadrangles (DOQs), digital raster graphics (DRGs), Landsat imagery, colonia boundaries, hydrography, demographics, and geographic names.

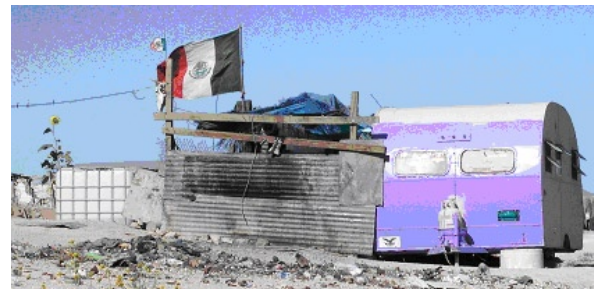

Figure 1. A house in a colonia of Agua Prieta, Sonora. Photograph by Hugo B. Rodríguez-Gallegos.

\section{Purpose}

The application

- provides Web-based planning tools for estimating development costs for the colonias,

- includes the integration of existing binational geospatial, statistical, and demographic data, and

- provides geographic-analysis tools that will enhance the decisionmaking processes of city and county planning departments.

Local government and nonprofit agencies can employ this system to facilitate access to grants, in order to improve living conditions in the colonias.

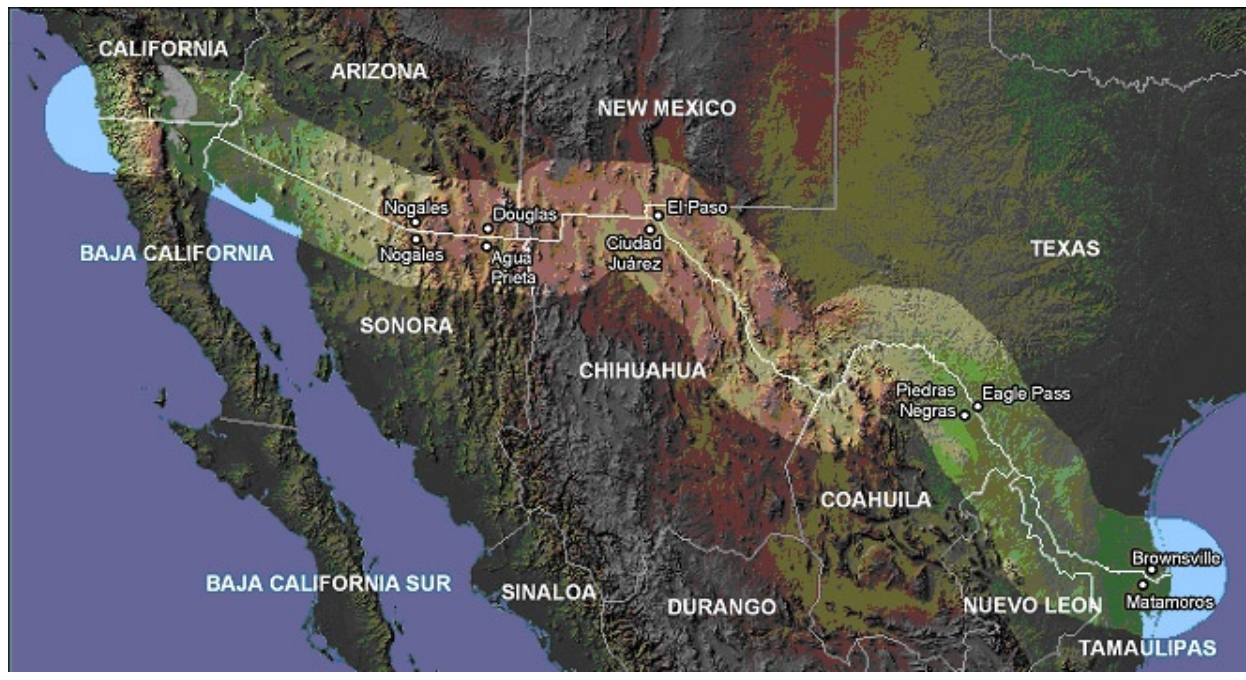

Figure 2. The sister cities of Eagle Pass/Piedras Negras, El Paso/Ciudad Juárez, Douglas/Agua Prieta, and Nogales/Nogales were chosen as project sites because of their location on the border and their international manufacturing and commercial opportunities, which have led to rapid spread of the colonias (Web-mapping services located at http://tx.usgs.gov/geography/prj_HUD.htm). 


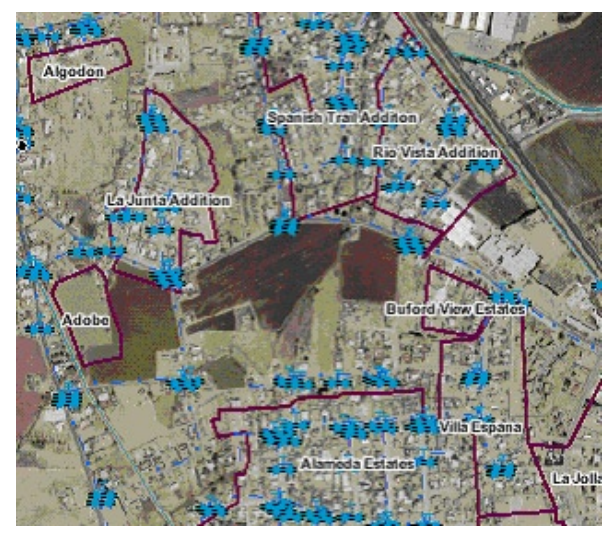

Figure 3. Waterlines and sewerlines in El Paso, Texas.

\section{Projects in Binational Sister Cities}

On the basis of local partnership opportunities, the GIS database developed for each sister-city pair includes additional layers that can facilitate planning for urban growth and the colonias' infrastructure needs.

The sister cities of Eagle Pass/Piedras Negras, El Paso/Ciudad Juárez, Douglas/ Agua Prieta, and Nogales/Nogales were chosen as project sites because of their location on the border and their international manufacturing and commercial opportunities, which have led to rapid spread of the colonias.

\section{El Paso/Ciudad Juárez}

The Web-based GIS database for El Paso/Ciudad Jarez was developed under

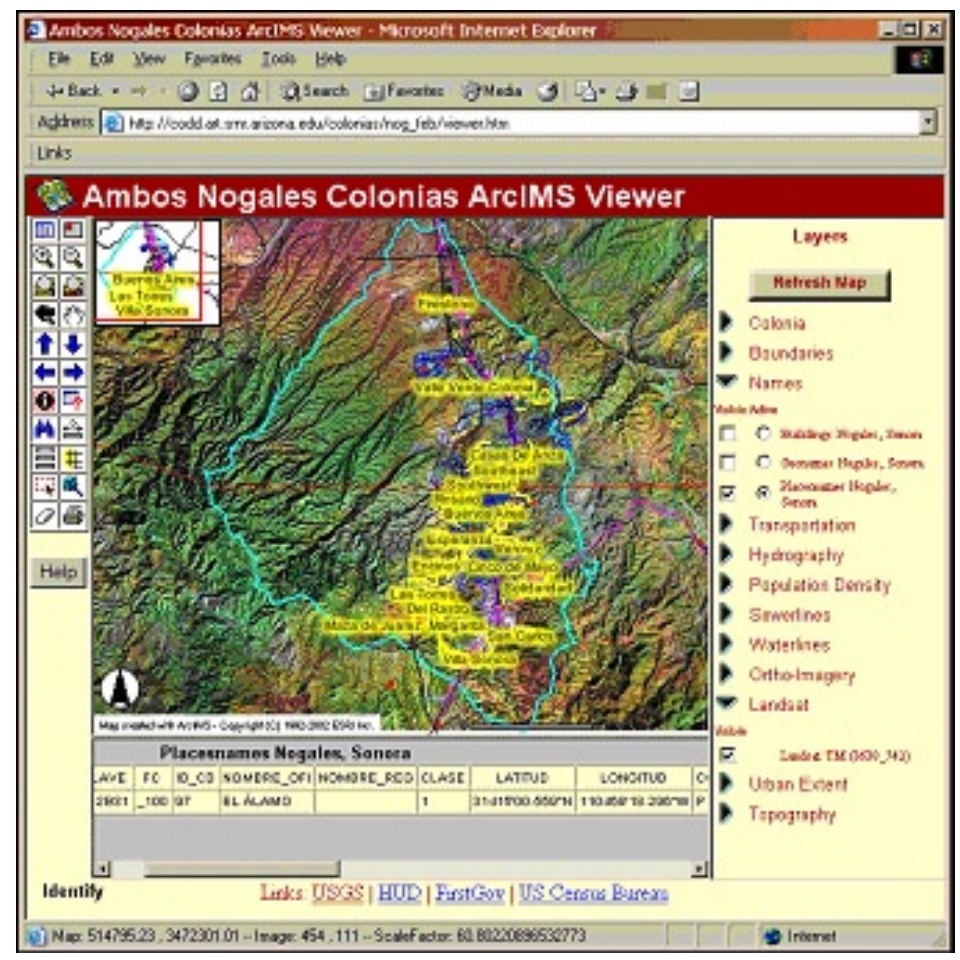

local partnership with the binational Paso Del Norte Mapping for Public Access collaboration, administered by the city of El Paso and the Instituto Municipal de Investigación y Planeación. Local data layers include such critical infrastructure as police, fire stations, hospitals, schools, boundaries for enterprise communities, "empowerment zones," and police, school, voter, and irrigation districts. Future plans include incorporation of local data from Doña Ana County, New Mexico, and geospatial-database access to the most current El Paso County Colonias Regional Water and Wastewater Plan.

\section{Eagle Pass/Piedras Negras}

Local partners that contributed data for Eagle Pass/Piedras Negras include the Middle Rio Grande Council of Governments, the Texas Water Development Board, and the city of Eagle Pass. Specific data layers include parcel ownership, waterlines and sewerlines, and critical infrastructure features. Future plans include incorporating zoning information, transportation-development plans, and Maverick County colonias master annexation plans.

\section{Douglas/Agua Prieta}

Partners that contributed geospatial data for Douglas/Agua Prieta to develop base maps for this project include the Border Environment Cooperation Commission-Comisión de Cooperación Ecológica Fronteriza (BECC-COCEF), Cochise County, Arizona, the city of Douglas, and the Municipio de Agua Prieta, Sonora. With the help of community members in the cities of Douglas and Agua Prieta, waterlines and sewer lines, inadequate housing structures, and colonias were identified and digitized. These data can be viewed in concert with resources identified by local youth groups and by other locality-reference information.

\section{Nogales/Nogales}

Many partners contributed geospatial data for Nogales/Nogales to develop base maps for this project, including the Secretaría de Infraestructura Urbana y Ecología (SIUE), the Arizona Department of Environmental Quality (ADEQ), the Instituto del Medio Ambiente y el Desarrollo Sustentable (IMADES), the Comisión de Agua Potable y Alcantarillado del Estado de Sonora (COAPAES), the University of Arizona Udall Center for Studies in Public Policy, the city of Nogales, Arizona, and the Municipio de Nogales, Sonora. Community members in the cities used waterlines, sewerlines, and inadequate housing structures to help identify colonias. Those areas identified by community members of Nogales, Sonora, were also identified by the SIUE as neighborhoods that are either "popular dwellings" or "precarious constructions," and these homogeneous areas can now be visualized online.

Laura M. Norman, Jean W. Parcher, and Alven H. Lam

Edited by

George A. Havach

Graphics by

Zachary D. Wilson and Laura M. Norman

Produced by

Sean M. Stone, Alan L. Vaughn, and Brent-Kaan White

\section{COOPERATING ORGANIZATIONS} U.S. Geological Survey

U.S. Department of Housing and Urban Development Instituto Nacional de Estadística Geografía e Informática

For more information, contact: Laura M. Norman, Inorman@usgs.gov Jean W. Parcher, jwparcher@usgs.gov Alven H. Lam, alven_h._lam@hud.gov

For information on other USGS products and services, call 1-888-ASK-USGS or visit the general interest publications Web site on mapping, geography, and related topics at mac.usgs.gov/mac/isb/ pubs/pubslists/.

For additional information, visit the ask.usgs.gov Web site or the USGS home page at www.usgs.gov.

Figure 4. Web-based GIS decision-support system established for Nogales/Nogales. 